\title{
A Review of Women's Career Issues
}

\author{
Wen Chen ${ }^{1, a}$ \\ ${ }^{1}$ East China University of Science and Technology, Shanghai 200237, China \\ a1195513154@qq.com
}

Keywords: female occupation, phenomenon, career issues

\begin{abstract}
The research on women's career is an important part of career research. In real life, women are facing a lot of problems caused by gender, which will affect their career development. This paper reviews the latest research progress of women's career, and the important consensus of the existing research on women's career and the corresponding four practical contradictions, on this basis, the organization should be know how to deal with the female career development problems in the future.
\end{abstract}

\section{Introduction}

In recent years, with the development of society and organization change, more and more women into the workplace, which triggered a huge changes in the structure of management thought, leadership and organization, and it will be more attention, especially for women [1]; not only that, from the boundary occupation career [2] to the variability of the occupation career [3] to the occupation career kaleidoscope [4], from the emphasis on the employment ability to focus on subjective occupation to successful work and family life. The change of organization development mode and the trend of the diversification of career concept show that it is necessary to take the gender factor into consideration.

More and more studies show that male and female career development difference not only on gender differences [5], but also by the organizational and social factors influence [6]. At least three key factors for women's career and career success alone as the focus of the study in the necessity of provides convincing evidence, which leads to the women's career theory [7]. These three factors include: first, the influence of family responsibility of men's and women's employment in different [8]; the second, female professional psychological research show throughout their entire professional career development process [9-10]; the third, women in the top of the organization is relatively low, the proportion of limits the career development [11].

Career development of women is one of the important subjects in the interdisciplinary research, which provides the research results from different fields to enhance our understanding of women's career. These scattered research not only increases the research constructs the possibility of overlap with each other, but also caused the mutual contradiction between different backgrounds, different from the perspective of the conclusion of the study, is not conducive to the career women form a consistent understanding.

\section{Women's career and problems}

Through combing the research literature, this paper identifies the four interrelated phenomena. They represent the scholars through nearly 30 years of career women of unanimity; corresponding to the consensus of these studies, we also found that the reality practice and corresponding 
problems.

Phenomenon 1. Women's career includes more than the content of the work, and its career development embedded in the broad background of life. Recently, more and more studies have indicated that the career and life of modern women are interrelated and intertwined [12]. On this basis, a lot of research began to pay attention to the process and law of women's career development in the context of complex life. They through the research constructs the model of female career development "ABC", that in the whole life cycle of women, the authenticity, balance and challenges the relative importance depending on women's career and life background.

Question 1. Organizational practice requires women to separate career and life. More and more studies show that will work in the first sense of organization can not fully reflect the broader responsibility of modern women, the corresponding and organizational practices for trying to find a life of righteousness, and assume the dual responsibility of career and life of women is a kind of damage [13]. Therefore, the organization practical requirements of female employees will be completely separate occupation and life.

Phenomenon 2. Work and family life are women's career development and career success of the center. A comparative study shows that although men and women can play the multiple roles to achieve the role of gain, but gain direction is different, the male is from work to family, while the women from the family to work; at the same time, only women will experience loss of multiple roles, and work from the point to the family [14]. All researches conclusion shows that career and family are the center of the lives of women, and any on women career investigation and research must take into account women's family background and work, family interaction.

Question 2. The family is still the burden of women's career development in the organization. Seems to scholars to provide flexible working arrangements and reduce working hours for women's work family integration has basically reached a consensus, but for the use of the organization's work family welfare for career development with which is still controversial. Since women are the largest group of these so-called work family benefits, their career development is at a disadvantage, and the family has become a burden to women in the organization of career success.

Phenomenon 3. Women's career development presents a variety of patterns. In the career development process, Men and women bear different family responsibilities, women must be an important family issues integrated into the career development process. Therefore, White think women prefer flexible patterns of employment, and made a successful women career development stage model.

Question 3. Organizational recognition is still the traditional linear promotion career development model. Due to the friendly organization atmosphere, some women create more flexible career development pattern. So on the one hand can create more chances to develop, on the other hand to meet their pursuit of complete life.

Phenomenon 4. Human capital and social network support is the key capital of women's career development. Human capital is generally considered to be an important capital to promote professional development, and education, training and development opportunities, employment, experience and work flows can help individuals to accumulate human capital. Therefore, the social network is very important for women's career development, and the lack of social capital has become a key obstacle.

Question 4. With the lack of network and access, women are difficult to break the "glass ceiling" of the organization. Although some research shows that the key human capital investment and social support network of women has been significantly accumulated, the "glass ceiling" in organizations still exist in reality. Women usually describe their work in this way: To provide a large 
number of social connections, but rarely have the opportunity to get help to provide occupation development opportunities visible work experience.

\section{To promote the development of women's career}

Organization practice research prospects for many studies by exploring the reasons for the lack of women in senior leadership for women career and career success research made a contribution.

Firstly, Organizational structure needs to be adjusted. Since the aware of female career development varies according to the life cycle dynamic change rules, the organization should make corresponding adjustment of the structure, in order to adapt to the needs of female career and life in the field of integrated development. Therefore, future research should more in exploring the different organizational structure and female career success relationship efforts.

Secondly, remodeling of organizational norms. Promotion opportunities and fair are considered to be the key factors of women's career development. From the promotion opportunity, as our previous review, from superior support for women within the organization promotion is the core contribution. From a fair point of view, the unfair phenomenon of male and female differences in organizational differences does exist. In addition, many of the organizations that do not seem to be involved in gender differentiation are more likely to have a negative impact on women's career development.

Thirdly, organizational culture change. From the front of the agreement we can see that modern women to work transactional and non transactional have attached great importance to and they tried to involved in the dual role of work and family. Therefore, in order to tap the potential of women's development, we need to provide support for their career development in the aspects of the formulation and implementation of policy organization; on the contrary, if you can not provide the appropriate resources and encourage, then female talent depreciation and loss status will be difficult to get change [15]. As women assume multiple roles and facing various choices, the organization for them to create inclusive and supportive climate, which will be able to greatly enhance the level of organizational commitment and loyalty of female employees.

\section{Summary}

Future research should be more in different mining organization value concept and its relation with female culture and career success of efforts, such as exploring and verify that the organization if you have to actively support the work of family welfare policy leaders, the harvest of female managers at a higher level of organizational commitment, organizational citizenship behavior and satisfaction; provide management support and role models and complete life friendly organization culture organization will be able to attract and retain outstanding female employees and the proposition.

However, compared with foreign countries, the research on the career of women in our country is in a backward state. Has been made from the foreign female occupation career problems results, we get the following enlightenment: first, to actively with international standards, combined with China's national conditions, the localization of research devoted to the problems of China's female occupation career; second, to actively explore the particularity of Chinese female career problems, which should not be ignored Chinese the traditional culture and values of female occupation career; third, it makes the empirical research on specific industries and specific groups, such as the factors of female occupation path model, impact, empirical research on successful 
women; fourth, to play the advantages of multi subjects, comprehensive utilization of various disciplines, such as psychology, sociology, management science and organizational behavior research, the absorption of researchers from different disciplines of interdisciplinary research.

\section{Reference:}

[1] Burke R J. Are families damaging to careers?[J]. Women in Management Review, 1997, 12(8): 320-324.

[2] Arthur M B. The boundaryless career: A new perspective for organizational inquiry [J]. Journal of Organizational Behavior, 1994, 15(4): 295-306.

[3] Hall V. Dancing on the ceiling: A study of women managers in education [M]. SAGE, 1996.

[4] Swan S H, Main K M, Liu F, et al. Decrease in anogenital distance among male infants with prenatal phthalate exposure [J]. Environmental health perspectives, 2005: 1056-1061.

[5] Edwin L. Herr Distinguished Professor of Education (Counselor Education and Counseling Psychology). Career Development and Its Practice: A Historical Perspective [J]. Career Development Quarterly, 2001, 49(3): 196-211.

[6] Fagenson-Eland E, Baugh G. Career paths, networking, and mentoring [J]. Women at work-leadershipfor the next century, 2000: 145-161.

[7] O'Neil D A, Bilimoria D. Women's career development phases: Idealism, endurance, and reinvention [J]. Career Development International, 1996, 10(3): 168-189.

[8] Wajcman J. Managing like a man: Women and men in corporate management [M]. John Wiley \& Sons, 2013.

[9] Gilligan C. In a different voice [M]. Harvard University Press, 1982.

[10] Fondas N. Feminization Unveiled: Management Qualities in Contemporary Writings [J]. Academy of Management Review, 1997, 22(1): 257-282.

[11] Ely R J. The power in demography: Women's social constructions of gender identity at work [J]. Academy of Management journal, 1995, 38(3): 589-634.

[12] Powell G N, Mainiero L A. Cross-currents in the river of time: Conceptualizing the complexities of women's careers [J]. Journal of Management, 1992, 18(2): 215-237.

[13] Pringle J K, McCulloch Dixon K. Re-incarnating life in the careers of women [J]. Career Development International, 2003, 8(6): 291-300.

[14] Rothbard N P. Enriching or depleting? The dynamics of engagement in work and family roles [J]. Administrative Science Quarterly, 2001, 46(4): 655-684.

[15] Marshall J. Women managers moving on: Exploring career and life choices [M]. Thomson Learning, 1995. 